\title{
Intention to Donate Money via Social Network Site: Perspective from a Developing Country
}

\author{
(Keinginan untuk Menyumbangkan Wang melalui Rangkaian Laman Sosial: Perspektif dari Sebuah Negara
} Membangun)

Tze Kiat Lui

(Faculty of Business and Finance, Universiti Tunku Abdul Rahman)

Mohd Haniff Zainuldin

(Faculty of Business and Accountancy, University of Malaya)

\section{ABSTRACT}

Charity fundraising is challenging, yet the social network site (SNS) has changed the way to drive money donations. The largest SNS user group in Malaysia is comprised of university students. However, they are the least contributed group in making donations. This study examines the factors influencing the intentions of students to donate money via SNS. A cross-sectional online survey was conducted, and the data from 216 questionnaires were analysed using multiple linear regression. Using the extended theory of planned behaviour, three constructs, namely, descriptive norm, perceived behavioural control, and Internet technology feature, were found to significantly affecting the intention for online donations. Normalising the majority's performance in a similar reference group and making students feel comfortable sharing their online giving information have positive effects on donation intention via SNS. The young people were also concerned about the Internet functionality to perform monetary donation over SNS. The other two constructs that are, attitude and past behaviour, were not significant towards intention to donate via SNS. The findings offered several suggestions to non-profit organisations to raise the awareness of online giving among students, as to shape them to become future donors for far-reaching decades.

Keywords: Social network; internet; online donation; charity; intention to donate

ABSTRAK

Pengumpulan dana amal sememangnya mencabar namun laman sosial (SNS) telah mengubah cara untuk mendorong sumbangan wang. Kumpulan pengguna SNS terbesar di Malaysia terdiri daripada pelajar universiti, namun mereka adalah kumpulan yang paling sedikit dalam memberikan sumbangan. Kajian ini mengkaji faktor-faktor yang mempengaruhi keinginan pelajar untuk menderma wang melalui SNS. Satu tinjauan keratan rentas dalam talian telah dilakukan, dan data daripada 216 soal selidik telah dianalisis menggunakan regresi linier berganda. Dengan menggunakan teori tingkah laku terancang lanjutan, kajian ini mendapati tiga konstruk iaitu, norma deskriptif, jangkaan kawalan tingkah laku, dan ciri teknologi Internet adalah merupakan faktor-faktor signifikan yang mempengaruhi keinginan untuk memberikan sumbangan dalam talian. Menormalkan prestasi majoriti dalam kumpulan rujukan yang serupa dan membuat pelajar berasa selesa untuk berkongsi maklumat dalam talian dapat memberikan kesan positif terhadap keinginan untuk menderma melalui SNS. Golongan muda juga peka kepada fungsi Internet untuk membuat sumbangan wang melalui SNS. Dua konstruk lain, iaitu, sikap dan tingkah laku masa lalu didapati tidak signifikan terhadap keinginan untuk menderma melalui SNS. Hasil kajian ini menawarkan beberapa cadangan kepada organisasi bukan berasaskan keuntungan untuk meningkatkan kesedaran mengenai pemberian dalam talian di kalangan pelajar, demi membentuk mereka menjadi penderma pada masa depan.

Kata kunci: Rangkaian sosial; internet; sumbangan atas talian; dana amal; keinginan untuk menderma

\section{INTRODUCTION}

In recent years, web-based applications and services in Malaysia are getting diversified and constantly thriving in society. The Internet has enabled online applications to target specific markets globally with relative ease. In the statistical data provided by the Malaysian Communications and Multimedia Commission (MCMC), a survey delineated that the Internet users of the total Malaysian population had risen from $76.9 \%$ in
2016 to $87.4 \%$ in 2018 (MCMC, 2018). The data has indicated the high usage of the Internet, including the most popular service, i.e., social network site (SNS). MCMC (2018) reported that the Internet had become a social engagement tool in which SNS carries a total of $85.6 \%$ usages of the Internet in Malaysia. In the latest Digital 2019 report issued by We Are Social and Hootsuite, Malaysia was ranked in the top five countries globally with the highest social media penetration using mobile devices in Southeast Asia (NST 2019). In general, 
SNS is recognised as a web-based service that enables individuals to construct, share, and view their list of connections and postings in the system (Boyd \& Ellison 2008). This web-based service will lead to an increase of opportunities for groups of people who share a firm's goals and objectives (Wojciechowski 2009).

With SNS, Internet users have the unprecedented ability to offer help either in monetary form or in moral support through an online network. Many non-profit organisations have tapped into a multitude of functions and features provided by the SNS to crowd-source substantial funds for charity events. The SNS can act as a platform for non-governmental organisations (NGOs) and donors to organise events directly and easily, without wasting time receiving and sending donations online (Waters \& Feneley 2013). Furthermore, the roles of SNS include sourcing information, forming groups, and promoting donation and charity activities (Lovejoy \& Saxton, 2012). In addition, SNS effectively gathers a larger base of online supporters for non-profits organisations drawing funds and assistance for their activities ( $\mathrm{Li}$ et al. 2018).

Although SNS has gone popular among Malaysians, the Charities Aid Foundation (CAF) (2016) reported that Malaysia was dropped out of the Top 10 of the World Giving Index ranking in 2016. In the recent report by CAF (2018), the population aged 15-29 years old has the lowest participation rate in donating money, which is only $24 \%$ of the total population (Figure 1 ). Besides, the population group aged 15-29 years old was found to have fewer donations between 2015 and 2017, particularly in developing countries. In fact, this age group is made up of the largest SNS users in Malaysia (Ab Rahim 2015). According to the Institutional Research (2018), the top 5 majority age groups of university students fall between the ages of 18 to 29 years old, thus matching the age group reported by CAF (2018) and Ab Rahim (2015). Ab Rahim et al. (2015) also claimed that most Malaysian students have habits of using the SNS for learning and socialising purposes, including browsing in groups and reading posts and newsfeeds. Notably, donation practices linking to charity were less emphasised among university students.

In other words, the university students were the least contributed group in making donations despite they are the most active SNS users in Malaysia. Due to that, most NGOs believe in the application of social media to raise brand awareness (Nonprofit Tech for Good 2018), particularly among young adults and students (Harden et al., 2015). Furthermore, Pentecost and Andrews (2010) revealed the importance of the Internet in improving the students' perceptions of charity, which ultimately spurs their intended donation behaviour. Although most university students view income as an issue in restricting their involvement in charity donations, increasing their awareness of charitable behaviour in the long term is necessary. Harden et al. (2015) stressed that students would face their later life as working adults, and hence, investigating the factors influencing them at an earlier stage to become future donors is essential for farreaching decades of social donations and volunteering. In this respect, university students' group ought to not be overlooked in the Malaysian market, as Kok et al. (2011) contended that Malaysian university students should be cultivated with humanity aspect via participating in charity events and fundraising.

The study of donor behaviour and intention to donate money has not been explored extensively in recent years (Kashif et al. 2015), particularly among the younger adults (Yuan et al. 2011) and in the perspective of developing countries (Kashif \& De Run 2015). It is confirmed that Internet technology positively influences users' intention to make donations through the SNS (Ahn et al. 2018; Sura et al. 2017). However, little empirical research has been focused on examining the determinants of young people's intention to make donations via SNS

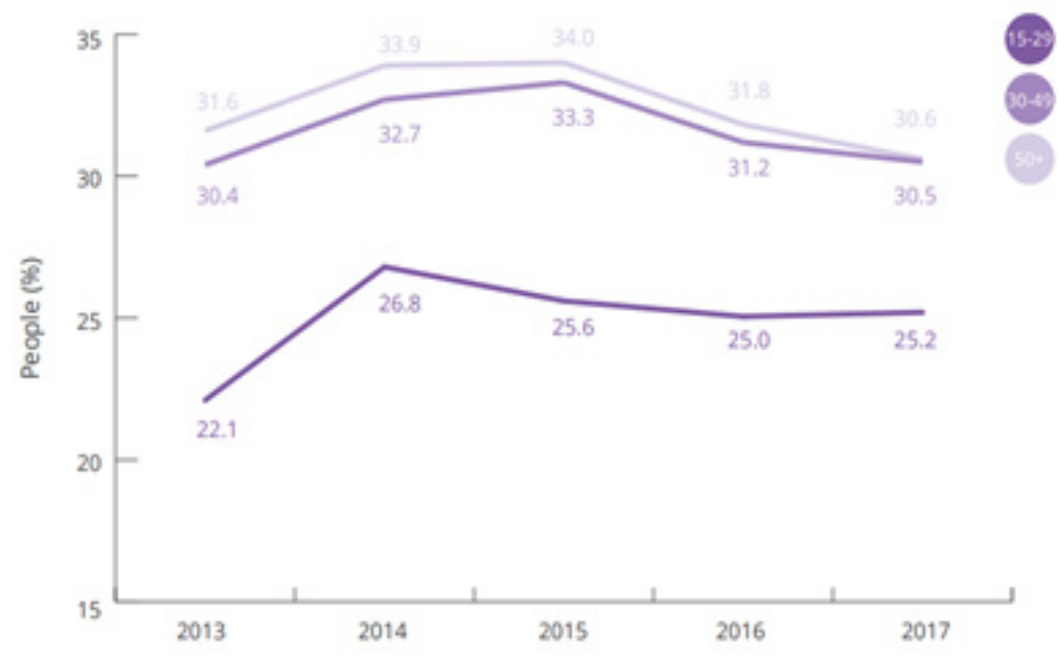

FIGURE 1. The global participation of money donation based on age Source: CAF (2018) 
(Lee et al. 2016). This study offers an extended theory of planned behaviour (ETPB) framework to scrutinise the online donation intention of younger people in a developing country setting. Besides, existing studies have been focused on examining the intrinsic factors, but less attention was given to the extrinsic factors (Sura et al. 2017). Cherry (2013) argued that extrinsic factor has its own role affecting people to make donations. By taking these literature gaps into account, this study attempts to investigate the intrinsic and extrinsic factors influencing the intention of the largest group of SNS users, i.e., Malaysian university students, to donate money via SNS. It should be noted that this study aims to examine the intention to donate via SNS rather than examining the actual donation behaviour; thus, the young age group of SNS users with low disposable income was selected as sample respondents. By understanding the intention to donate via SNS, charity and non-governmental organisations (NGOs) can build their coherent marketing strategy in social media to encourage more online donations. In addition, this study could be of aid to the non-profit organisation to set the tone of marketing plans for young adults and further comprehends the socio-cultural environment of an Asian country. This study stimulates that younger adults are very active in SNS, and hence, they may become longlife donors when they are convinced of the practices at a younger age (Hart et al. 2007). Besides, social media is an effective way to motivate the youngster to engage in donating activities (Kim \& Lee 2014). Therefore, it is vital to instil awareness among the young generation to shape a culture of helping the community via an online donation that is believed to become the future trend in achieving charity activities.

The subsequent sections of this study are organised as follows: Section 2 discusses the literature review covering theoretical background, hypotheses development, and the proposed research model, Section 3 describes the research method used in this study, Section 4 explains the findings of the empirical analysis, and Section 5 concludes the results, including contributions, implications, and limitations of the study.

\section{LITERATURE REVIEW}

\section{THEORETICAL BACKGROUND}

Individual behaviour is a logical process involving some aspects that could influence an individual's decision (Kashif et al. 2015). The underlying TPB refers to the behavioural decision that is not being made spontaneously, however, the reasoned process determines the decision in which behaviour is influenced (Smith \& McSweeney 2007). TPB was established as the Theory of Reasoned Action in 1980 to make a prediction of an individual's intention to involve in a behaviour at a particular place and time. The theory can explain the behaviours of people who can exert self-control (LaMorte 2016). Although the TPB has been used in many Western studies to explain the donation intentions, the paucity of such incorporation in the developing country perspective is more notable (Kashif et al. 2015). In light of the growth of SNS users in Malaysia, it is worth tapping into TPB to clarify the donation intention of the younger generation as to cultivate a healthy socio-cultural practice on the Internet.

The extant literature in the field of monetary donation has been adapting the TPB. For example, Ahn et al. (2018), Linden (2011), Knowles et al. (2012), Smith and McSweeney (2007), and Sura et al. (2017) have demonstrated the potency of TPB as the power predictor model upon human donation intentions. The TPB consists of three constructs which are subjective norms, perceived behavioural control (PBC), control, and attitude. However, instead of using the classic TPB model, Kashif et al. (2015), Knowles et al. (2012), and Smith and McSweeney (2007) framed their research using the extended version. The TPB has been evolving over time. Subsequently, the extended TPB (ETPB) will provide an opportunity to dredge further in predicting human intention. The extended TPB by Konkoly and Perloff (1990) has divided the subjective norms into two, namely, injunctive norms and descriptive norms, in order to provide extensive justification on charitable intent. Besides, the role of past behaviour towards donor's intention has been added to the original model (Sutton 2010), as Knowles et al. (2012) strongly proposed this predictor for future ETPB setting in relation to charitable giving research.

This study uses extended TPB by employing the two original predictors (i.e., PBC and attitude), adding with the descriptive norm and past behaviour of which taken from the prior ETPB models. Notwithstanding Konkoly and Perloff (1990), who suggested injunctive norms and descriptive norms in their ETPB, this study chooses the descriptive norm only, lending support to the findings by Amran and Nee (2012) that failed to demonstrate the significant relationship between purchase intention of low-income group and injunctive norm in the Malaysian context. This study uses a sample of university students who are mostly grouped as low-income groups; thus, it is comprehensible that many students do not seek social approval in making donations. Similarly, De Leeuw et al. (2015) found that the injunctive norm was insignificant while the descriptive norm was significant after separately examined the descriptive and injunctive norms based on a survey of 108 students. Additionally, Agerstrom et al. (2016) reported the positive and effective role of the descriptive norm among university student to increase their charitable giving rather than the injunctive norm.

An extrinsic factor is added to the ETPB to make this study more relevant in the SNS context. Hoefer (2012) stated that the traditional method to collect money for donation has become less effective due to many alternative methods, mostly online donation platforms. Besides, many NGOs have switched from manual to 
online collection methods for monetary donations, as the Internet can offer a more efficient, less time, direct, easy, and quick way of transferring funds (Sura et al. 2017). Therefore, it is vital to put the Internet technology features as part of the predictors towards online donations, as SNS is highly dependent on the Internet connection. By going through the SNS to collect online donations, the Internet technology features are critical extrinsic factors to provide different web technologies and services to encourage people for online giving. Cherry (2013) claimed that the effect of extrinsic factors was stronger when the users were weak in intrinsic orientation, and hence, Ahn et al. (2018) and Sura et al. (2017) have included Internet technology in their studies and revealed a significant association of Internet technology on online monetary donations among South Koreans.

\section{INTENTION TO DONATE VIA SNS}

The use of social media is a growing trend in Malaysia, and it is prevalent among younger adults. However, university students were reported at a poor level in making donations (CAF 2018). The result reflects a lack of awareness and practices of charity by the younger adults. Mostafa et al. (2020) established a Charity Fundraising Information System (CFIS) framework and gathered the records of charity activities through the mobile application. The authors reported that Facebook, Twitter, and Instagram were the most widespread online social platforms to engage in fundraising and charity activities. However, donors aged $18-28$ years old have the lowest philanthropy contributions. By conducting focus groups on university students aged between 18 and 25 years old in the UK, Dean (2020) supported the existence of social network effects, but peer motivation remained a stronger factor in leading to charity and donations. The authors also highlighted that the close connection with family and friends is more powerful than the influence of celebrity and large-scale gimmick in online giving campaigns. This is because the university students were brought up in an environment where they were advised not to believe the messages posted online without further investigation or clarification. Based on these analogous arguments, there is a possibility that young people have a negative perception of donations over SNS. Therefore, a more micro-level study is needed to investigate the intention to donate money via SNS in the Malaysian context. The reasons for the willingness to donate could be instigated by intrinsic and extrinsic factors. Intrinsic factors are referred to as extending one's capacities to do something that reflects on his/her inner value $(\mathrm{Oh} \& \mathrm{Ki}$ 2018) while extrinsic factors are described as exercising something due to outside influences (Ahn et al. 2017). Various intrinsic factors have been linked to donor's intention, such as attitude (Da Silva et al., 2020), past behaviour (Kashif et al. 2015), and self-efficacy (Ergun \& Avci 2018), whereas examples of extrinsic factors are religious belief, charity project, (Sarea \& Bin-Nashwan
2021), and Internet technology features (Ahn et al. 2018). To fit the theoretical framework discussed above, the intrinsic factors of this study are attitude, descriptive norm, PBC, and past behaviours, while the extrinsic factor is the Internet technology feature.

\section{HYPOTHESIS DEVELOPMENT}

There are five hypotheses developed in this study, and the proposed research model is shown in Figure 2.

\section{ATTITUDE AND INTENTION TO DONATE VIA SNS}

Ajzen (1991) described the attitude towards a certain behaviour that could anticipate someone's intention. As such, the belief system or the function of salient information develops the attitude linked to the behaviour, entailing the strength of the attitude determined by the relevancy of information (Ajzen 2001). In studying the donors' behaviour, Knowles et al. (2012) confirmed that attitude is a solid predictor towards monetary donation, especially when the donors were informed of their contributions tangibly helping the recipients. In addition, Da Silva et al. (2020) reported a significant effect of attitude in influencing intention for charity and donations due to the brand orientation that develops communication to the potential Brazilian donors. Regarding donation via SNS, Hajjar et al. (2016) found a positive relationship between attitude and organ donations among social media users, which resulted from awareness programs of religious legislation. In a nutshell, the salient information delivered to the potential donors leans to an attitude to perform online donations via SNS. Therefore, this study proposes the following hypothesis:

$\mathrm{H}_{1}$ There is a positive relationship between attitude and intention to donate via SNS.

\section{DESCRIPTIVE NORM AND INTENTION TO DONATE VIA SNS}

Descriptive norm refers to an individual's perception of whether others are in a similar reference group displaying a specific behaviour (McMillan \& Conner 2003; Pavlova \& Silbereisen 2015). Agerstrom et al. (2016) conducted experiments on 192 university students in Sweden in which the findings showed an increase in charitable donations with effective signalling of descriptive social norms. Likewise, Shang and Croson (2009) explored the effects of descriptive norms in a radio station by announcing the amount donated by the previous donors and revealed that the next donors were influenced to improve their donation behaviour. In relation to social media, Kim and Lee (2015) revealed that descriptive norms modelled by interpersonal influences affect the users to interact with Facebook Ads. In short, people tend to donate money when the majority in the group had done the same via the social medium. In this respect, the following hypothesis is proposed: 
$\mathrm{H}_{2}$ There is a positive relationship between descriptive norm and intention to donate via SNS.

\section{PERCEIVED BEHAVIOURAL CONTROL AND INTENTION TO DONATE VIA SNS}

PBC refers to an individual's perceived ease or difficulty in successfully presenting the behaviour. The effort used to accomplish a particular goal can increase the perception of stronger behavioural control (Ajzen, 2002). Using an observation experiment, Ajzen and Madden (1986) examined the undergraduates' intention with PBC towards a goal of attaining grade A in which the results supported $\mathrm{PBC}$ as the significant predictor. Both studies by Ajzen (1991) and Ajzen and Madden (1986) agreed that TPB concedes more accurate prediction with PCB over intentions and goal attainment than the theory of reasoned action. Besides, Lawson-Body et al. (2018) have found that the relationship between PBC and intention to donate was mediated by the presence of social media. As online sharing is an uncomplicated effort, PBC and SNS are correlated for most consumers feel uninhibited to share online content with their friends or relatives (Demangeot \& Broderick 2010). Having said that, SNS users tend to donate online to share this information over social media, and hence, this study proposes the following hypothesis:

$\mathrm{H}_{3}$ There is a positive relationship between PBC and intention to donate via SNS.

\section{PAST BEHAVIOUR AND INTENTION TO DONATE VIA SNS}

Sutton et al. (2010) defined past behaviour as the repeated performance of which behaviour is determined by someone's earlier involvement rather than relying on the cognitive skills. The aspect of past behaviour has been recognised as a potent predictor of behavioural intentions (Bozionelos \& Bennett 1999). Smith and McSweeney (2007) incorporated self-reported behaviour to investigate the effectiveness of TPB and the significant evidence found in the relationship between past behaviour and intention to donate. Using a survey of 221 questionnaires in Malaysia, Kashif et al. (2015) testified that past behaviour is a significant factor in donation intention, and it is suggested to be linked with customer loyalty. Furthermore, Rauniar et al. (2014) confirmed the significance of past experience using social media to shape the intention of future usage. With respect to the role of past behaviours in donating money via SNS, this study proposes the following hypothesis:

$\mathrm{H}_{4}$ There is a positive relationship between past behaviour and intention to donate via SNS.

\section{INTERNET TECHNOLOGY FEATURE AND INTENTION TO DONATE VIA SNS}

In general, online activities must be connected to the Internet, including charitable giving held in the SNS. Some vital features of the Internet technology are timesaving, immediacy, and security (Treiblmaier \& Pollach 2006), which could be helpful to raise online donations. Past literature has demonstrated the role of Internet technology features in shaping intention to donate. For example, Shier and Handy (2012) stated that Internet technology was perceived as a safe, trustworthy, effective, and efficient instrument, which ultimately influenced online donors behaviour to perform donation. Similarly, Wong and Jusoff (2011) asserted that charity advocacy was adopted in the social network because of the growth of Internet technology features, specifically time-saving, security, and simplicity. More recent literature, such as those in Ahn et al. (2018) and Sura et al. (2017), have

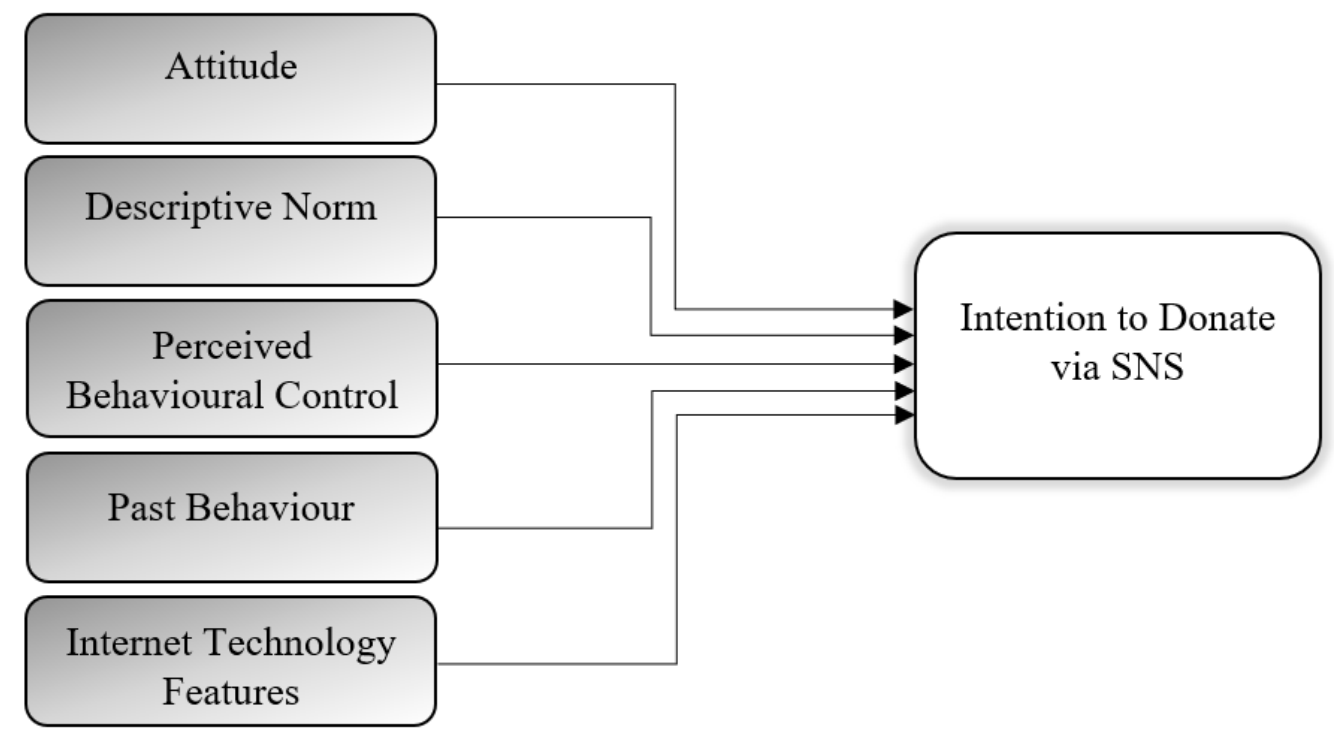

FIGURE 2. Proposed research model 
revealed that the Internet technology feature was a significant predictor and an external antecedence upon online donations among Malaysians and South Koreans. In this regard, the Internet technology features enable the SNS to raise monetary donations in the global market better than the traditional ways; thus, the following hypothesis is proposed.

$\mathrm{H}_{5}$ There is a positive relationship between Internet technology feature and intention to donate via SNS.

\section{RESEARCH METHODS}

A cross-sectional design using a self-administered survey questionnaire was used to explain how each predictor is correlated to the intention to donate via SNS. The questionnaire survey approach was used in this study since the natural judgmental indicator could be derived by allocating a score to each type of practice development activity (Currie 2009). Furthermore, the questionnaire method gathers a huge amount of information from a large population within a short period (Saul 2018) on top of providing a standardised way to ensure uniformity in responses (Mathiyazhagan 2010).

\section{SAMPLING DESIGN}

Non-probability sampling procedure (i.e., convenience sampling) was applied due to no precise sampling frame discovered in the population and to meet the geographical and time contiguity of the target respondents. The Malaysian university students were deemed the appropriate target sample because they were made up of the largest SNS users in Malaysia (Ab Rahim et al. 2015) and represent their later lives as working adults and potential donors (Harden et al. 2015). It is important to understand their intended donation behaviour at an earlier stage in order to raise awareness of charitable behaviour in the long term. For sample size, Hinkin (1995) recommended the ratio of 1:4 to $1: 10$ based on the number of items in the questionnaire. Therefore, 25 questions were developed, and a maximum of 250 respondents was required.

\section{RESEARCH INSTRUMENT}

All sample items of the questionnaire were adapted from the past literature. The sample items of the five constructs, namely, attitude, descriptive norm, PBC, and past behaviour, Internet technology feature, and intention to donate, were referred from Knowles et al. (2012), Smith and McSweeney (2007), and Sura et al. (2017). Intention to donate was assigned with 6 sample items, while the other constructs were assigned with 4 samples items each (as shown in Appendix A). The questionnaire draft was also sent to two expert panels for review. A pilot test was conducted using 10 percent of the total sample (Hertzog, 2008), i.e., 25 university students, to ensure all the items met the internal validity of the constructs (Nunnally 1978).

\section{DATA COLLECTION PROCEDURE}

The online survey was distributed to Selangor, Johor, and Sabah because these states have the highest number of Malaysian Internet users (MCMC 2020). In each state, one public and one private university were selected for this survey, respectively. Hence, a total of 6 universities were approached with voluntary participation. An e-mail invitation was sent, and those who agreed to participate in the research were asked to complete the questionnaire. A consent form was attached on the first page of the questionnaire. The definition for each construct was clearly explained before the questions part. The online survey took approximately 10 minutes to complete. Over the course of 6 weeks, only 222 questionnaires were successfully collected. Some incomplete questionnaires were removed, leaving a final total of 216 questionnaires, with a response rate of 86.40 percent.

\section{MEASURES}

The multiple-item of the questionnaire was measured using the 5-point Likert scale starting from 1 (strongly disagree) to 5 (strongly agree). The 5-point Likert scale can minimise confusion, improve response rate and quality, and generate higher reliability (Bouranta et al. 2009). The data collected from the questionnaires were later analysed using Statistical Analysis System (SAS). There are three main parts of data analysis: descriptive analysis, scale measurement, and inferential analysis. The measurement of descriptive analysis includes frequency, percentage, mean, and standard deviation. The scale measurement covers reliability and multicollinearity tests. Finally, the inferential analysis contains multiple linear regression (MLR). The equations for MLR and descriptions of the independent variable (IV) and dependent variable (DV) are shown in Table 1.

TABLE 1. Regression equation

\begin{tabular}{cc}
\hline \multicolumn{2}{c}{$\mathrm{Y}=\beta_{0}+\beta_{1} \mathrm{X}_{1}+\beta_{2} \mathrm{X}_{2}+\beta_{3} \mathrm{X}_{3}+\beta_{4} \mathrm{X}_{4}+\beta_{5} \mathrm{X}_{5}+\mathrm{e}$} \\
\hline $\mathrm{Y}$ & Intention to donate via SNS \\
$\mathrm{X}_{1}$ & Attitude \\
$\mathrm{X}_{2}$ & Descriptive norm \\
$\mathrm{X}_{3}$ & Perceived behavioural control \\
$\mathrm{X}_{4}$ & Past behaviour \\
$\mathrm{X}_{5}$ & Internet technology feature \\
$\beta_{0}$ & Regression constant (Intercept) \\
$\beta_{1}-\beta_{5}$ & Regression beta coefficient association with each $\mathrm{X}_{\mathrm{i}}$ \\
$\mathrm{e}$ & Error term \\
\hline
\end{tabular}




\section{RESULTS}

\section{DESCRIPTIVE ANALYSIS}

The demographic characteristics entailed six aspects: the respondent's gender, age, race, state, university, and current education level (Table 2). The percentage of gender denotes an almost balanced distribution between male respondents $(54.17 \%)$ and female respondents $(45.83 \%)$. More than half of the total respondents $(51.85 \%)$ fall in the age group of $22-24$ years old. This observation explains the domination of undergraduate students using SNS on the Internet, consistent with the study reported by Ab Rahim et al. (2015). The questionnaires were distributed to Selangor (52.31\%), Johor $(26.85 \%)$, and Sabah $(20.83 \%)$, and more than half of the total respondents came from Selangor. These statistical data was also corresponded with the report from MCMC (2020), stating that Selangor has 21.5 percent of Internet users from the total population, followed by Johor (11.5\%) and Sabah (11.0\%). One public and one private university were approached in each state, and Uni 1 and 2 are in Selangor, followed by Uni 3 and 4 in Johor, and Uni 5 and 6 in Sabah. Over 70 percent of the total respondents had education status at degree level, which they were also the largest group of the respondents.

TABLE 2. Descriptive data

\begin{tabular}{lccc}
\hline Demographic Characteristics & Frequency & Percentage (\%) \\
\hline Gender & Male & 117 & 54.17 \\
Age (years) & Female & 99 & 45.83 \\
& $18-21$ & 94 & 43.52 \\
& $22-24$ & 112 & 51.85 \\
State & $25-28$ & 10 & 4.63 \\
& Selangor & 113 & 52.31 \\
\multirow{4}{*}{ University } & Johor & 58 & 26.85 \\
& Sabah & 45 & 20.83 \\
& Uni 1 (Public) & 57 & 26.39 \\
& Uni 2 (Private) & 57 & 26.39 \\
& Uni 3 (Public) & 29 & 13.43 \\
Current & Uni 5 (Private) & 28 & 12.96 \\
education & Uni 6 (Private) & 23 & 10.65 \\
level & Diploma & 22 & 10.19 \\
& Degree & 168 & 10.19 \\
\hline
\end{tabular}

\section{CENTRAL TENDENCIES MEASUREMENT OF CONSTRUCTS}

Table 3 describes the measurement of central tendencies for all items of each construct. All sample items have been listed in Appendix A. The means of all IVs' items are ranged between 2.4259 and 4.0000 , indicating moderate preferences when answering in the 5-point Likert scale. In a similar study, Reid and Wood (2008) reported similar means where items of donation intention factors were ranged between 2.76 and 6.46 when a 7-point Likert scale is used. It explained that most respondents were less likely to select neither "strongly" disagree nor agree in expressing their views on each factor. The items of DV indicated the mean values from 4.1898 to 4.4074 , implying most respondents have a strong intention to donate using SNS. The standard deviations of all items were valued from 0.7349 to 1.2266 , indicating each construct were responded with lesser variability. Nevertheless, the measurement scales in the next section will determine the appropriateness to use these constructs for inferential analysis.

TABLE 3. Statistical data of central tendencies measurement

\begin{tabular}{lccc}
\hline Construct & Item & Mean & Standard Deviation \\
\hline Attitude & A 1 & 2.5694 & 1.0586 \\
& A 2 & 2.5648 & 1.0367 \\
& A 3 & 2.7361 & 1.0652 \\
Descriptive norm & A 4 & 2.7593 & 1.2266 \\
& D 1 & 3.9676 & 0.9119 \\
& D 2 & 3.8981 & 0.8990 \\
PBC & D 3 & 3.8935 & 0.9464 \\
& D 4 & 3.8796 & 0.8542 \\
Past behaviour & B 1 & 3.9398 & 0.8133 \\
& B 2 & 3.9769 & 0.7742 \\
Internet technology & B 3 & 4.0000 & 0.8573 \\
feature & B 4 & 3.9630 & 0.8564 \\
& P 1 & 2.5880 & 1.0123 \\
& P 2 & 2.5417 & 0.9539 \\
Intention to donate & P 3 & 2.4259 & 0.8702 \\
via SNS & P 4 & 2.5046 & 1.0826 \\
& T 2 & 3.6806 & 0.9523 \\
& T 3 & 3.6315 & 0.9059 \\
& T 4 & 3.7083 & 0.8857 \\
& F 2 & 4.4074 & 0.9115 \\
& F 3 & 4.3657 & 0.8074 \\
& F 4 & 4.2593 & 0.7349 \\
F 5 & 4.3380 & 0.8218 \\
& F 6 & 4.2963 & 0.8055 \\
& & & 0.7687 \\
\hline \multirow{5}{*}{ SCALE MEASUREMENT } & \\
& & & \\
& & & \\
& &
\end{tabular}

The reliability test results in Table 4 also showed that all sample items were valued above 0.7 in Cronbach's Alpha, suggesting a high-reliability level of all constructs (Bougie \& Sekaran 2020). The Pearson correlation analysis results were shown in Table 5. The purpose of this analysis is to check the validity of the IVs with the DV by measuring the relationship between the two variables (Koop 2009). All the coefficient values are 
ranged between 0.00008 and 0.69835 ; that is below 0.8 and hence, no indication of multicollinearity problem (Bougie \& Sekaran 2020).

TABLE 4. Reliability test

\begin{tabular}{lcc}
\hline Constructs & $\begin{array}{c}\text { Number } \\
\text { of items }\end{array}$ & $\begin{array}{c}\text { Cronbach's } \\
\text { Alpha }\end{array}$ \\
\hline Attitude & 4 & 0.843303 \\
Descriptive norm & 4 & 0.780124 \\
PBC & 4 & 0.726284 \\
Past behaviour & 4 & 0.800336 \\
Internet technology feature & 4 & 0.791155 \\
Intention to donate via SNS & 6 & 0.832438 \\
\hline
\end{tabular}

\section{MULTIPLE LINEAR REGRESSION ANALYSIS}

Table 6 presents the results of multiple linear regression analysis. The model is significant at 1 percent level with an F-value of 62.922. It has an R-squared value of 0.6494, which suggested that $64.94 \%$ of the variance in intention is explained by the independent variables. The model did not suffer from a heteroskedasticity problem as the chi-square value of 28.41 is not significant at 5 percent level. Again, there is no indication of a multicollinearity problem in this study, as all the variance inflation (VIF) values range between 1.00964 and 1.84388; less than 10 points (Bougie \& Sekaran 2020). The adjusted R-square was recorded at 0.6411 , signifying over $60 \%$ of the constructs used in the model were deemed appropriate. Based on the results of $\mathrm{P}$-value $(<0.05)$ and parameter estimate $(+/-)$, descriptive norm, $\mathrm{PBC}$, and Internet technology feature were positively significant predictors, while the effects of attitude and past behaviours were not significant towards intention to donate via SNS. Therefore, the test results have supported $\mathrm{H}_{2}, \mathrm{H}_{3}$, and $\mathrm{H}_{5}$, but $\mathrm{H}_{1}$ and $\mathrm{H}_{4}$ were rejected.

\section{DISCUSSION}

The results in Table 6 can be further explained by observing predictors with significant positive relationships, i.e., descriptive norm, PCB, and Internet technology feature. The role of descriptive norm seemed to be effective, supporting the findings in Agerstrom et al. (2016) and Shang and Croson (2009) that normalising the majority's performance in a similar reference group has its effect of increasing the donation intention. The young people held more support toward donation intention, perceived that sharing information about a charitable contribution is easy, particularly in social media. The result is in accordance with Franklin et al. (2016), who stated that young people liked to express their involvement in charity via social media, which was a way to promote social work education. Therefore, intention to donate increased when students feel comfortable sharing their online giving information in the SNS. As for the Internet technology feature, Ahn et al. (2018), Ou-Yang et al. (2017), and Sura et al. (2017) presented a similar finding that users were highly concerned about the Internet functionality upon charitable giving. This study offers a piece of evidence that students' intention was influenced by the security, reliability, trustworthiness, and effectiveness of the Internet to perform monetary donation over SNS.

The effects of attitude and past behaviour were not significant in this study. The attitude was hypothesised as anticipation developed from the belief system or the function of salient information related to online donation. However, such a predictor did not influence the intention of students to donate via SNS, thus contradicted the studies by Da Silva et al. (2020), Hajjar et al. (2016), and Knowles et al. (2012). It is possible that the user-generated contents on social media were not highly credible to the users (Sura et al., 2017), especially students who are brought up in an environment where they were advised not to simply believe the messages posted online (Dean, 2020). Past behaviour was not an important predictor as students applied cognitive skills to determine their donation intention rather than relied on someone's earlier involvement. The findings by Kashif et al. (2015), Smith and McSweeney (2007), and Sutton et al. (2010) failed to support this predictor. Van der Linden (2011) stated that past behaviour was an indicator of habit strength but did not necessarily relate to the frequency of the behaviour. Thus, students who have intentions to donate via SNS in the past might not have the same intentions constantly in the future.

\section{CONCLUSION}

Online fundraising is growing fast in the SNS, and many non-profit organisations worldwide have caught in this trend. Nevertheless, an online donation has appeared as a radical concept to young people who resisted to participate, especially Malaysian university students. A survey of 25,632 students from six Malaysian public universities indicated $96 \%$ of the students faced financial burdens that resulted from the economic changes (O'Malley 2016). Therefore, students would find their income as an issue restricting their involvement in charity donations. However, this study did not focus on the actual donation made by the students rather than the intention to donate via SNS. Besides, students were noted as the largest SNS users' group, and they will be representing later life as working adults. This study intended to raise the awareness of online giving to the students at an earlier stage to shape them to become future donors for far-reaching decades.

The key findings in this study highlighted the significance of descriptive norm, $\mathrm{PCB}$, and Internet 
technology feature as predictors in shaping the younger generation to donate using SNS. Several implications for both theory and practice are worth to be highlighted. From a theoretical view, this study extended the TBP framework to measure younger people's intention to donate via the online platform, particularly in a developing country setting. It delivered a significant part to the extant body of knowledge, which mostly studied in the Western environment (Hossain Parash et al. 2020). The results also enhanced the existing literature pertaining to online donation by investigating both intrinsic (i.e., attitude, descriptive norm, PCB, and past behaviour) and extrinsic (i.e., Internet feature) factors toward donation intention. From the practical perspective, the findings have suggested the need to increase understanding about online donation to younger people by promoting the role of the descriptive norm, PCB, and Internet technology feature. To pull the young SNS users' interest, non-profit organisations should pay attention to build a collectivist culture for online giving via SNS and encourage more sharing about the charity-related events in the popular social media platforms. In addition, a specific mechanism on the Internet should be developed to increase security, reliability, trustworthiness, and effectiveness to perform donation monetarily over SNS. This is because young people are on the alert with the benefits and drawbacks of Internet technology features. For example, a mobile wallet can be applied in online giving to facilitate faster transaction processing in a secure manner (Lui et al., 2021).

Although this study has offered several key findings, future research should consider extending the current ETBP to test different intrinsic and extrinsic predictors, especially during pandemic times as the socio-economic system is affected and many people need more donations. The target sample of this study may limit the generalisation to the entire population in Malaysia. Therefore, future studies should extend the representative sample to different age range groups, such as working professionals and older adults. The target sample also can be expanded to other developing countries to take a broader view of this topic. All in all, this study serves as a fundamental reference to help non-profit organisations understand their potential donors' intentions who heavily relied on the SNS norms.

\section{REFERENCES}

Ab Rahim, N. Z., Abidin, S. N. Z. \& Abidin, W. Z. 2015. The habits of social networking site (SNS) use among postgraduate students. Jurnal Teknologi 76(1): 329-334.

Agerstrom, J., Carlsson, R., Nicklasson, L. \& Guntell, L. 2016. Using descriptive social norms to increase charitable giving: The power of local norms. Journal of Economic Psychology 52: 147-153.

Ahn, J-C, Sura, S. \& An, J-C. 2018. Intention to donate via social network sites (SNSs): A comparison study between Malaysian and South Korean users. Information Technology \& People 31(4): 910-926.
Ajzen, I. \& Madden, T. J. 1986. Prediction of goal directed behavior: Attitudes, intentions, and perceived behavioral control. Journal of Experimental Social Psychology 22(5): 453-474.

Ajzen, I. 1991. The theory of planned behavior. Organizational Behavior and Human Decision Processes 50(2): 179-211.

Ajzen, I. 2001. Nature and operation of attitudes. Annual Review of Psychology 52(1): 27-58.

Ajzen, I. 2002. Perceived behavioral control, self-efficacy, locus of control, and the theory of planned behavior ${ }^{1}$. Journal of Applied Social Psychology 32(4): 665-683.

Amran, A. \& Nee, G. 2012. Determinants of behavioural intention on sustainable food consumption among consumers of low income group: Empirical evidence from Malaysia. WEI International European Academic Conference Proceedings, Zagreb, Croatia, 84-93.

Bougie, R. \& Sekaran, U. 2020. Research Methods for Business: A Skill-Building Approach. 8th Edition. Hoboken, New Jersey: John Wiley \& Sons Inc.

Bouranta, N., Chitiris, L. \& Paravantis, J. 2009. The relationship between internal and external service quality. International Journal of Contemporary Hospitality Management 21(3): 275-293.

Boyd, D.M. \& Ellison, N.B. 2008. Social network sites: Definition, history, and scholarship. Journal of ComputerMediated Communication Social 13(1): 210-230.

Bozionelos, G. \& Bennett, P. 1999. The theory of planned behaviour as predictor of exercise. Journal of Health Psychology 4(4): 517-529.

CAF 2016. CAF World Giving Index 2016. The World's Leading Study of Generosity. Available at https://www.cafonline. org/docs/default-source/about-us-publications/1950a wgi_2016_report_web_v2_241016.pdf

CAF 2018. CAF World Giving Index 2018. The World's Leading Study of Generosity. Available at https://www. cafonline.org/docs/default-source/about-us-publications/ caf_wgi2018 report_webnopw_2379a_261018.pdf

Cherry, K. 2013. Differences between extrinsic and intrinsic motivation. Very Well Mind. Available at https://www. verywellmind.com/differences-between-extrinsic-andintrinsic-motivation-2795384

Currie, K. 2009. Using survey data to assist theoretical sampling in grounded theory research. Nurse Researcher 17(1): 24-33.

Da Silva, L.C., Mainardes, E.W., Teixeira, A.M.C. \& Costa Junior, L. 2020. Brand orientation of nonprofit organizations and its relationship with the attitude toward charity and donation intention. International Review on Public and Nonprofit Marketing 17: 353-373.

De Leeuw, A., Valois, P., Ajzen, I. \& Schmidt, P. 2015. Using the theory of planned behavior to identify key beliefs underlying pro-environmental behavior in high-school students: Implications for educational interventions. Journal of Environmental Psychology 42: 128-138.

Dean, J. 2020. Student perceptions and experiences of charity on social media: The authenticity of offline networks in online giving. Voluntary Sector Review 11(1): 41-57.

Demangeot, C. \& Broderick, A.J. 2010. Consumer perceptions of online shopping environments. Psychology \& Marketing 30(6): 461-469.

Ergun, E. \& Avci, U. 2018. Knowledge sharing self-efficacy, motivation and sense of community as predictors of knowledge receiving and giving behaviors. Educational Technology \& Society 21(3): 60-73. 
Franklin, P., Hossain, R. \& Coren, E. 2016. Social media and young people's involvement in social work education. Social Work Education 35(3): 344-356.

Hajjar, W.M., Abdulqader, S.A.B., Aldayel, S.S., Alfardan, A.W. \& Alzaidy, N.I. 2016. Knowledge, attitudes, and beliefs toward organ donation among social media users. Transplantation Proceedings 48(7): 2418-2422.

Harden, J., Jukes, I. \& Joyce, P. 2015. An insight into the charitable giving of young adults \& students. Available at https://2uc9gf10ufco12f962jlxrpd-wpengine.netdna-ssl. com/wp-content/uploads/2015/09/result-document.pdf

Hart, D., Donnelly, T.M., Youniss, J. \& Atkins, R. 2007. High school community service as a predictor of adult voting and volunteering. American Educational Research Journal 44(1): 197-219.

Hertzog, M.A. 2008. Considerations in determining sample size for pilot studies. Research in Nursing \& Health 31(4): 180-191.

Hinkin, T. 1995. A review of scale development practices in the study of organizations. Journal of Management 21(5): 967-988.

Hoefer, R. 2012. From web site visitor to online contributor: Three Internet fundraising techniques for nonprofits. Social Work 57(4): 361-365.

Hossain Parash, M.T.H., Suki, N.M., Shimmi, S.C., Hossain, A.B.M.T. \& Murthy, K.D. 2020. Examining students' intention to perform voluntary blood donation using a theory of planned behaviour: A structural equation modelling approach. Transfusion Clinique et Biologique 27(2): 70-77.

Institutional Research 2018. Undergraduate \& graduate students by age and gender. Available at http://www2. southeastern.edu/Administration/Inst-Research/Student/ data.cgi?stuage.txt

Kashif, M. \& De Run, E.C. 2015. Money donations intentions among Muslim donors: An extended theory of planned behavior model. International Journal of Nonprofit and Voluntary Sector Marketing 20(1): 84-96.

Kashif, M., Sarifuddin, S. \& Hassan, A. 2015. Charity donation: Intentions and behaviour. Marketing Intelligence \& Planning 33(1): 90-102.

Kim, S., Lee, J. \& Yoon, D. 2015. Norms in social media: The application of theory of reasoned action and personal norms in predicting interactions with Facebook page like ads. Communication Research Reports 32(4): 322-331.

Kim, Y. \& Lee, W.-N. 2014. Networking for philanthropy: Increasing volunteer behavior via social networking sites. Cyberpsychology, Behavior, and Social Networking 17(3): 160-165.

Knowles, S.R., Hyde, M.K. \& White, K.M. 2012. Predictors of young people's charitable intentions to donate money: An extended theory of planned behavior perspective. Journal of Applied Social Psychology 42(9): 2096-2110.

Kok. J.K., Cheah, P. K. \& Ang, S.M. 2011. The role of the university: Malaysian students' perceptions. Available at http://www.ipedr.com/vol5/no1/20-H00060.pdf

Konkoly, T.H. \& Perloff, R.M. 1990. Applying the theory of reasoned action to charitable intent. Psychological Reports 67(1): 91-94.

Koop, G. 2009. Analysis of Economic Data. West Sussex, England: John Wiley \& Sons Ltd.

LaMorte, W.W. 2016. The theory of planned behavior. Available at http://sphweb.bumc.bu.edu/otlt/MPH-Modules/SB/ BehavioralChangeTheories/BehavioralChangeTheories3. html
Lawson-Body, A., Jackson, J. \& Willoughby, L. 2018. Factors predicting donors' intention to give: Mediating role of social media presence. Issues in Information Systems 19(1): 91-97.

Lee, C.S., Shin, M.H., Lee, Y. \& Jang, H.Y. 2016. A study on the factors influencing on young people's donation attitude : A comparison of school levels. Indian Journal of Science and Technology 9(43): 1-7.

Li, Y.Z., He, T.L., Song, Y.R., Yang, Z. \& Zhou, R.T. 2018. Factors impacting donors' intention to donate to charitable crowd-funding projects in China: A UTAUT-based model. Information Communication and Society 21(3): 404-415.

Linden, S.V.D. 2011. Charitable intent: A moral or social construct? A revised theory of planned behavior model. Current Psychology 30: 355-374.

Lovejoy, K. \& Saxton, G. 2012. Information, community and action: How nonprofit organizations use social media. Journal of Computer-Mediated Communication 17(3): 337-353.

Lui, T.K., Zainuldin, M.H., Yii, K-J., Lau, L-S. \& Go, Y-H. 2021. Consumer adoption of Alipay in Malaysia: The mediation effect of perceived ease of use and perceived usefulness. Pertanika Journal of Social Science and Humanities 29(1): 389-418.

Mathiyazhagan, T. 2010. Survey research method. Media Mimansa 14A(4): 34-82.

MCMC 2018. Internet Users Survey 2018. Available at https:// www.mcmc.gov.my/skmmgovmy/media/General/ pdf/ Internet-Users-Survey-2018.pdf

MCMC 2020. Internet Users Survey 2020. Available at https:// www.mcmc.gov.my/skmmgovmy/media/ General/pdf/ IUS-2020-Report.pdf

McMillan, B. \& Conner, M. 2003. Using the theory of planned behaviour to understand alcohol and tobacco use in students. Psychology, Health and Medicine 8(3): 317-328.

Mostafa, S.A., Mustapha, A., Shamala, P., Obaid, O.I. \& Khalaf, B.A. 2020. Social networking mobile apps framework for organizing and facilitating charitable and voluntary activities in Malaysia. Bulletin of Electrical Engineering and Informatics 9(2): 827-833.

Nonprofit Tech for Good 2018. Technology Report. Available at http://techreport.ngo/wp-content/uploads/2018-TechReport-English.pdf

NST 2019(January). Malaysia ranks top 5 globally in mobile social media penetration, highest in region. New Straits Times. Available at https://www.nst.com.my/lifestyle/ bots/2019/01/456119/malaysia-ranks-top-5-globallymobile-social-media-penetration-highest

O’Malley, B. 2016(January). Many students are struggling to afford meals - Survey. University World News. Available at https://www.universityworldnews.com/post. php?story $=20160112212332541$

Oh, J. \& Ki, E-J. 2018. What makes association members donate more? Factors influencing members' donation amount in membership-based professional associations. VOLUNTAS: International Journal of Voluntary and Nonprofit Organizations, 30: 800-810.

Ou-Yang, J., Bei, C.H., He, B. \& Rong, X. 2017. Factors influencing blood donation: A cross-sectional survey in Guangzhou, China. Transfusion Medicine 27(4): 256-267.

Pavlova, M.K. \& Silbereisen, R.K. 2015. Supportive Social context and intentions for civic and political participation: An application of the theory of planned behaviour. Journal of Community \& Applied Social Psychology 25(5): 432446 . 
Pentecost, R. \& Andrews, L. 2010. Differences between students and non-students' willingness to donate to a charitable organisation. International Journal of Nonprofit and Voluntary Sector Marketing 15(2): 122-136.

Rauniar, R., Rawski, G., Yang, J. \& Johnson, B. 2014). Technology acceptance model (TAM) and social media usage: An empirical study on Facebook. Journal of Enterprise Information Management 27(1): 6-30.

Reid, M.\& Wood, A. 2008. An investigation into blood donation intentions among non-donors. International Journal of Nonprofit and Voluntary Sector Marketing 13(1): 31-43.

Sarea, A. \& Bin-Nashwan, S.A. 2021. Guide to giving during the COVID-19 pandemic: The moderating role of religious belief on donor attitude. International Journal of Ethics and Systems 37(1): 90-104.

Saul, M. 2018. Questionnaire. Simply Psychology. Available at https://www.simplypsychology.org/questionnaires.htm

Shang, J. \& Croson, R. 2009. Field experiments in charitable contribution: The impact of social influence on the voluntary provision of public goods. The Economic Journal 119(540): 1422-1439.

Shier, M.L. \& Handy, F. 2012. Understanding online behavior: The role of donor characteristics, perceptions of Internet, website and program and influence from social networks. International Journal of Nonprofit and Voluntary Sector Marketing 17(3): 219-230.

Smith, J.R. \& McSweeney, A. 2007. Charitable Giving: The effectiveness of a revised theory of planned behaviour model in predicting donating intentions and behaviour. Journal of Community \& Applied Social Psychology 17(5): 363-386.

Sura, S., Ahn, J. \& Lee, O. 2017. Factors influencing intention to donate via social network site (SNS): From Asian's perspective. Telematics and Informatics 34(1): 164-176.

Sutton, D., Baskerville, R. \& Cordery, C. 2010. A development agenda, the donor dollar, and voluntary failure David. Accounting, Business \& Financial History 20(2): 209229.
Treiblmaier, H. \& Pollach, I. 2006. A framework for measuring people's intention to donate online. The Tenth Pacific Asia Conference on Information Systems (Pacis): 808-819.

Van der Linden, S. 2011. Charitable intent: A moral or social construct? A revised theory of planned behavior model. Current Psychology 30(4): 355-374.

Waters, R.D. \& Feneley, K.L. 2013. Virtual stewardship in the age of new media: Have nonprofit organizations' moved beyond Web 1.0 strategies? International Journal of Nonprofit and Voluntary Sector Marketing 18(3): 216230.

Wojciechowski, A. 2009. Models of charity donations and project funding in social networks. In Lecture Notes in Computer Science (including subseries Lecture Notes in Artificial Intelligence and Lecture Notes in Bioinformatics) 5872(LNCS): 454-463.

Wong, D.M.L. \& Jussof, K. 2011. Social network in charity advocacy. World Applied Science Journal 12: 65-72.

Yuan, S., Hoffman, M., Lu, Q., Goldfinger, D. \& Ziman, A. 2011. Motivating factors and deterrents for blood donation among donors at a university campus-based collection center. Transfusion 51(11): 2438-2444.

Tze Kiat Lui

Faculty of Business and Finance

Universiti Tunku Abdul Rahman

Jalan Universiti, Bandar Barat

31900 Kampar, Perak, MALAYSIA.

E-Mail: luitk@utar.edu.my

Mohd Haniff Zainuldin (corresponding author)

Faculty of Business and Accountancy

University of Malaya

Jalan Profesor Diraja Ungku Aziz

50603 Kuala Lumpur, MALAYSIA.

E-Mail: hanif.zainuldin@um.edu.my 


\begin{tabular}{|c|c|c|c|}
\hline Variable & Item & Description & Source \\
\hline \multirow[t]{4}{*}{ Attitude } & A1 & The charity benefits a particular population & \multirow{4}{*}{ Knowles et al. (2012) } \\
\hline & A2 & To improve human/ environmental circumstances & \\
\hline & $\mathrm{A} 3$ & Believe charity represents a good or worthy cause & \\
\hline & A4 & Believe have an obligation to help others/want to help make a difference & \\
\hline \multirow[t]{4}{*}{$\begin{array}{l}\text { Descriptive } \\
\text { norms }\end{array}$} & D1 & $\begin{array}{l}\text { Think of those people important to you. What percentage of them do you } \\
\text { think donate money to charities or community service organisations }\end{array}$ & \multirow{22}{*}{$\begin{array}{l}\text { Smith and } \\
\text { McSweeney (2007) }\end{array}$} \\
\hline & $\mathrm{D} 2$ & $\begin{array}{l}\text { Most people who are important to me donate money to charities or } \\
\text { community service organisations }\end{array}$ & \\
\hline & D3 & $\begin{array}{l}\text { Those people closest to me do not donate money to charities or community } \\
\text { service organisations }\end{array}$ & \\
\hline & D4 & $\begin{array}{l}\text { How likely do you think it is that those important to you donate money to } \\
\text { charities or community service organisations }\end{array}$ & \\
\hline \multirow{4}{*}{$\begin{array}{l}\text { Perceived } \\
\text { behavioural } \\
\text { control }\end{array}$} & $\mathrm{H} 1$ & $\begin{array}{l}\text { If I wanted to, I could easily donate money to charities or community } \\
\text { service organisations }\end{array}$ & \\
\hline & $\mathrm{H} 2$ & $\begin{array}{l}\text { Overall, how much control do you have over whether you donate money to } \\
\text { charities or community service organisations }\end{array}$ & \\
\hline & $\mathrm{H} 3$ & $\begin{array}{l}\text { It is mostly up to me whether I donate money to charities or community } \\
\text { service organisations }\end{array}$ & \\
\hline & $\mathrm{H} 4$ & $\begin{array}{l}\text { Donating money to charities or community service organisations is easy for } \\
\text { me to do }\end{array}$ & \\
\hline \multirow[t]{4}{*}{ Past behaviour } & $\mathrm{P} 1$ & I do not donate money to charities or community service organisations & \\
\hline & $\mathrm{P} 2$ & $\begin{array}{l}\text { I did not donate money to charities or community service organisations in } \\
\text { the past }\end{array}$ & \\
\hline & P3 & $\begin{array}{l}\text { It is unusual for me to donate money to charities or community service } \\
\text { organisations }\end{array}$ & \\
\hline & $\mathrm{P} 4$ & I usually donate money to charities and community service organisations & \\
\hline \multirow{4}{*}{$\begin{array}{l}\text { Internet } \\
\text { technology factor }\end{array}$} & $\mathrm{T} 1$ & I am concerned about the Internet security & \\
\hline & $\mathrm{T} 2$ & I am concerned about the online transaction reliability & \\
\hline & $\mathrm{T} 3$ & I am concerned about the Internet trustworthiness & \\
\hline & $\mathrm{T} 4$ & I am concerned about Internet effectiveness & \\
\hline \multirow{6}{*}{$\begin{array}{l}\text { Intention to } \\
\text { donate via SNS }\end{array}$} & F1 & I have an intention to donate via SNS & \\
\hline & $\mathrm{F} 2$ & I have an intention to donate via SNS in the near future & \\
\hline & F3 & I plan to donate actively via SNS in the near future & \\
\hline & F4 & I plan to attend a donation program via SNS in the near future & \\
\hline & F5 & I have an intention to donate via SNS if I have a chance to do so & \\
\hline & F6 & I have an intention to donate more via SNS & \\
\hline
\end{tabular}

